\title{
Russian Journalism Theory in a Changing Global Context
}

\author{
Sergey Grigorievich Korkonosenko ${ }^{1}$ \\ ${ }^{1}$ Saint Petersburg State University, Saint Petersburg, Russia \\ Correspondence: Sergey Grigorievich Korkonosenko, Universitetskaya nab., 7/9, 199034, Saint Petersburg, \\ Russia.
}

Received: October 10, 2014 Accepted: October 21, 2014 Online Published: December 2, 2014

doi:10.5539/ass.v11n1p329

URL: http://dx.doi.org/10.5539/ass.v11n1p329

\begin{abstract}
The article considers a position of Russian journalism theory in international context and professional cooperation in this connection. Publications of Russian media scholars are practically unknown abroad. At the same time theoretical concepts from the West are poorly suited for adequate understanding of national journalism with its original traditions and professional characteristics. Russian research school should take the place of equal partner in the international community and act according to principles of mutually useful exchange. Global De-Westernization trend in media studies creates good conditions for this. The objective and subjective reasons of such a state of affairs are examined in the article. The main purpose of the paper consists in discovering contradictory relations of isolation / cooperation between Russian and international studies in journalism theory. The author also suggests ways to solution of this problem.
\end{abstract}

Keywords: international context, Russia, journalism theory, de-Westernization, research school, national tradition, partnership

\section{Introduction}

\subsection{De-Westernization Trend in Media Studies}

In the last decades, suggestions appeared more often to expand geographical horizons of reasoning on the condition and development of the mass media; and in this way to overcome actual isolation of the Western research culture from the world of the other. Some works, in which the central place belongs to the ideas of internationalization and de-Westernization of media studies, became an actual challenge to the stable system of representation and empirical basis. These works include John Downing's Internationalizing Media Theory: Transition, Power, Culture - Reflections on Media in Russia, Poland and Hungary. It was written in the book: “... crucially, the overwhelming body of media communication theory is based upon data from two spots, Britain and the United States, which have ... remarkably similar leitmotifs in their cultural, economic and political history that mark them out from most other nations on the planet" (Downing, 1996, p. x).

One may notice in brackets, the author substantially based the conclusions on Russian material. Then, the collective work under the leadership of J. Curran and M. J. Park De-Westernizing Media Studies (Curran and Park, 2000) aroused solidarity and attempts to continue the begun analysis. For example, Silvio Waisbord from the George Washington University is convinced: "De-Westernization implies opening up analytical horizons by considering cases from around the world that are not known either due to language obstacles or disinterest. Given that the importance of the non-West is not news for non-Westerner scholars, Curran and Park's goal is primarily to encourage curiosity about other regions among Anglo-American researchers" (Waisbord, 2013, p. 2).

Some well-known European scientists in turn, promoted similar theses and initiatives. For example, Daya Thussu, University of Westminster should be mentioned (Thussu, 2009) with his appeal to internationalize media studies via taking into consideration regional and national specificities. As a plenary speaker on the Mass media in the modern world conference in St Petersburg State University (2014 April) he offered very impressive formulation of the De-Westernization (internalization) trend in the global media studies: New globalization = "Anglobalization" + Rise of the Rest (nations). Such ideas gain strong support of Russian media theorists (Vartanova, 2012). 


\subsection{Contradiction of Internationalization and National Identity}

So, the global research context begins to change from separation and isolation (West vs. East) towards cooperation, may be not so radically and rapidly, but clearly. It should be taken into consideration in the Russian scholars' community, if it doesn't wish to be associated with a "methodological nationalism" (Ekecrantz, 2007, p. 169). The task is to recognize properly the main directions and demands of the changing process as well as desirable benefits and priorities.

Let's add a few words to the context, but from another side. Russia as a whole searches for its place in world contexts in many ways, including: culturally, politically, and economically. German professor Wolfgang Seiffert described this new historical situation in such words: "Russia is still undergoing a process of transformation from a Communist party system to a state of law, to democracy and a market economy. Much has been achieved, although Russia has also experienced certain setbacks. Despite all ... critique of its internal development or foreign-political positions, it has (once again) become a major power factor ... all efforts to align Russia to Western models would only fail and have failed, because you cannot take a country and nation the size of Russia with its history, language and culture and make it deny its own identity" (Seiffert, 2007).

In other words, there is an opposition between necessity of dialogue and understanding, on the one hand, and maintaining of national identity, on the other hand. This opposition closely relates to the field of media researches. The aim of the paper consists in discovering this contradiction in its real volume and forms of display. Next purpose is to reveal objective and subjective obstacles for arranging of interaction, and then, to specify some practical steps towards intensifying of the international cooperation.

\section{Description and Discussion}

\subsection{Long Disconnection}

One is compelled to recognize that in the field of journalism and media theory the situation looks rather pessimistically. The works of Russian researchers are scarcely known abroad, and there is no real demand for their textbooks in the universities of Europe and America.

This situation to some extend reflects a traditional Western attitude towards cultural sphere in Russia. According to the remarkable recognition of the American expert, Kathleen F. Parthé within the Soviet period: "Scholarship and journalism in the West ... focused to a large degree on what lay outside the official system - on samizdat (literature circulated underground), tamizdat (literature written in the USSR but published abroad), and, to some extent, on émigré literature ... The underlying assumptions are that 'delayed' literature (zaderzhannaia literatura), by virtue of its having been delayed, carries a uniformly higher value than anything that was officially published in the USSR, and that those who did publish through official channels necessarily compromised the truth and even the artistic quality of their works" (Parthé, 1992, p. ix). However even in the "closed" Soviet years Western classics were mentioned on a regular basis in journalism theory in Russia, though sometimes in a critical key which corresponded to the era. In essence, the deep tradition of discussion about the status of journalism and research in this area was generated. It should be prolonged and supported but upraised on qualitatively new level. It is necessary to worry not about individual authors, whose names are already well-known in the West, but about a plenty of researchers, if not the majority of them.

In fact, Russian experts have directly joined the international exchange of views on basic categories of a journalistic science, and there is a large set of acknowledgment to this. However, the primary problems are still far from solution. Generally saying, the majority of home scholars don't worry of existence of Russian works on the international level. Perhaps reasons of objective and subjective origins for such a situation exist?

\subsection{Organizational Obstacles on a Way to Partnership}

On an objective $\overline{\bar{y}}$ level, a long-term autotrophic development of a science within national limits (or, at least, irregular international interaction) is affected. The influence of this factor is being overcome in current decades. This is due to a strengthening tradition of participation in conferences and training abroad, organization of comparative research in partnership with foreign universities, and free access to foreign publications and databases. However, greater radical decisions are required for an intensification of international partnership.

For example, the situation with publication of research products in reviewed journals with a high world rating changes slowly. Historically, Russian scientists considered publishing monographs and fundamental course books as a most prestigious achievement. However, for a great deal of time the world practice has given priority to journal articles. Perhaps this different interpretation was a reason for the absence in Russia journals on journalism and media which are registered in the largest databases: Web of Science and Scopus. Russian authors are compelled to offer their works to leading foreign journals and adapt them to corresponding standards and 
theoretical traditions. There is no blame of this or that side; however it is a fact of complicated reality. Accordingly, Russians in principal are unable to have good results within these parameters.

It should be told, that the given situation is characteristic for national science as a whole. According to bibliographic statistics, in 2002 the U.S.A. with $32 \%$ headed the list of the countries having the greatest quantity of publications in Web of Science; Russia took the ninth place, with $3.09 \%$. Ten years later the share of Russia has decreased up to $2.06 \%$; the U.S.A. have kept the leadership though their share of articles has decreased up to $27.13 \%$ (Podorvanyuk, 2013).

Also, a tradition to organize in Russia the largest international forums only starts to develop. For a long time there has been a need to make a constant practice to invite conferences of associations such as the European Communication Research and Education Association (ECREA) and the International Association for Media and Communication Research (IAMCR). Useful experience of carrying out wide international discussions may be found at Lomonosov Moscow State University, St Petersburg State University, etc.

However, such events should not remain as extreme splashes of activity, but they should become a routine practice; not only at capital universities, but also in regions. Really, ECREA's conferences quite often are organized in provincial cities of Europe, and even in small settlements. At last, it is time to found in Russia the academic center for studying journalism and media within the territory of Central and Eastern Europe. Now such centers are organized in some foreign institutions such as: Universities of Birmingham and Nottingham (UK), Uppsala University (Sweden), Universities of Helsinki and Tampere (Finland), Harvard University (USA), etc. There are no such centers in Russia, at least as instituted research organizations and it is improbable to consider this state of affairs as optimum.

\subsection{Diversity of Journalism Theory}

On a subjective level, interest in integration into the world community is restrained by disbelief of the high dividends from such investments of intellectual capital. Firstly, it is difficult for home researchers to adapt unconditionally those doctrines which have been developed within the Western theory of journalism and experienced in the editorial process. Some European researchers also critically evaluate them, for example from Germany (Pöttker, 2011, pp. 10-11). Are universal Western traditions of objectivity and impartiality, as it is categorically declared in media theory so strong in practical journalism? Otherwise, do they so reliably determine a formation of uniform style of journalistic activity? Some results of the empirical projects devoted to this theme are published. One of them may be found in the proceedings of the ECREA conference, Diversity of Journalisms (July, 2011, Pamplona, Spain). A rather unexpected effect was caused by the program of interviews with journalists in eighteen countries: "Overall, the findings point to important differences between journalistic cultures across the globe. If there is such thing as a global homogenization of news work, we believe that it has still a long way to go" (Hanitzsch \& Mellado, 2011, p. 398).

Secondly, a theory developing in the West couldn't be treated as the ideal of harmony and accuracy. For example, "The prominent feature of media researches is certain freedom in use of terms and designations, which sometimes leads to a terminological disorder, to a designation of opposite processes by the same term" (Dunas, 2013 b, p. 8). We must say even more sharply: some casual names have appeared in the global theoretical language which cannot be translated into a language of sense. In this respect different "post" and "new" are especially remarkable ("new media"). "Prefix 'post' always means inability to define an essence of the object. We, therefore, give it the most simple - time - definiteness ... An adjective 'new' carries out the same function ... But in what this new consists - we do not say concretely and theoretically" (Vorontsov \& Volovich, 2012, p. 12). Thirdly, the Western theory of journalism is not in the least holistic and homogenous in conceptual dimension. There is a rich spectrum of directions within it, including mutually exclusive ones (Sapunov, 2012). At the same time the majority of different schools in the West have a common feature; namely their mass communication base. This characteristic strongly narrows a corner of sight on journalism and is atypical for the Russian scientific tradition. In the West media researches normally are considered as social and political disciplines while in Russia (mostly) they traditionally belong to philological branch of sciences.

\subsection{Cooperation of Different Cultures?}

As it seems, here we find one of the key points of divergence of the Russian research tradition with the Western paradigm. Distinction in theoretical viewpoints is an effect of a difference in experience of practice, which for theorists serves as the object of attention and predetermines vectors of scientific interest. Experts know well that historically and genetically Russian journalism is undividedly connected with literature, and accordingly, it developed as a literary-centric activity in the forms and professional ideology. Correspondingly, an active role of the author follows, essentially more active than it is accepted in Western journalism which worships objectivity 
and the neutral interpretation of the fact. Known Polish media analyst, Karol Jakubowicz has remarked in this connection: "[In Central and Eastern European countries they want journalists to become a mouthpiece for the people]. That ... is a reflection of the traditional role of the intelligentsia in Central and Eastern European countries. This results in a type of journalism that is conviction-driven. By subordinating their work to promoting social and political change, journalists must necessarily opt for a partisan, advocacy-oriented and campaigning style of writing ..." (Jakubowicz, 2001, p. 75).

Besides theoretical disputation on the used notions and evaluations, great cultural differentiation of Western and Eastern journalism was truly caught there. On this platform, the analogous divergence in journalism theory should be taken into account. The reflection of the truth of events never was rejected in Russian journalism, both in practice and in theory. Also, great attention was paid to the literary quality of a product, rich set of genres and forms, author's personality, and the like. Publications should be attractive to the public for other reasons than just to gain information about events, solution of problems, and so forth. Readers also feel pleasure from the reading of a high-quality text or the viewing of a skillfully made telecast. Such divergences make impossible simple copying of Western experience and methodology in Russian media, both in practice and in theory. This is a part of general problem of searching the ways to cooperation of different cultures. In turn, one main mistake of many observers of the Russian media theory and practice is. They regularly use the so-called transitological paradigm of analysis. Professor Colin Sparks (British, now from Hong Kong) examined explanatory potential of the transitological theory in the fields of politics and media in post-communist countries. As he writes: "At least, the model of political change advanced by transitology is that there are observable twin process of democratic political change and of market economies.... This approach also strongly influences much of the writing about media in former communist countries... In other words, the really-existing media of different countries are measured against what has come to be known as the 'liberal model'. [The analysis of media changes in Russia, Poland and China] demonstrated that transitology gives very little insight into the prevailing situations" (Sparks, 2008, p. 7, 9).

There are radical questions in this connection. Perhaps such countries needn't accept the Western liberal project? Who knows? This is not a question of transitology per se; a mostly political approach quite often forces scholars to compare the incomparable, in essence - media phenomena created by different cultures. Shortly saying, not only political criteria should be used for the estimation of the media realities and not political ones play a decisive role in a complex of journalism theory.

\subsection{Dialogic Approach Needed}

Finally, Western does not mean global. The authoritative researchers emphasize, that there is diversity on a map of media and communications theories. According to John Downing, besides Britain and the United States: "The other nations on whose experience and culture media communication theory has mostly been based have been Germany, France and Italy, although the rapid growth of media studies in the Canadian and Australian academies has recently added those nations to the list" (Downing, 1996, p. x).

D. McQuail increases this list when he mentions candidates to be recognized as original national schools: France and the francophone area; the United Kingdom; Germany; the Scandinavian region; the Mediterranean region with Italy leading and Spain following (McQuail, 2009, p. 288). Of course, there is no Russia amongst these countries as well as, for example, Asian or Central and Eastern European states. It means that only scientists from these "forgotten" regions are capable to make the map of media theories more pluralistic and more realistic. So, all relating to Russia in this article has great importance for many national theoretical schools. The idea of equal cooperation meets a strong support in the works which develop the de-Westernizing paradigm in the field of journalism studies. For example the researchers from South Africa write in this connection: "The difference between a dialogic and an inclusive approach is important. Even if diverse journalisms are included in a global purview, some of them could still be marginalized ... as 'alternative' journalisms ... and therefore unable to exert pressure on the dominant mainstream to change ... in a truly dialogic approach $<\ldots>$ Inclusive approaches thus far have resulted in the 'reluctant' acceptance of models that differ from Anglo-American ones" (Wasserman \& de Beer, 2009, p. 429).

\section{Conclusions}

What to do? Thus, within a theme of the international context for the Russian research of journalism and mass media, there are some dominant tasks. The first and the most essential among these, at a level of an axiom, is a necessity to exist in this context and to do much, including active studying it, taking from it productive ideas, senses, techniques of work, and contacts. In this connection, Russian scholars must substantially change their academic traditions, from more "literary" style to strong argumentation according to international standards. 
Secondly, a clear representation is needed on a condition of world science, which has such characteristics as discrepancy, heterogeneity, and imperfection. Thirdly, the task is to bring to a world research practice best elements of knowledge and experience, which may be found in national science. If the context is international, it means it is being formed with our active participation in a role of the subject of action, instead of on the basis of noncritical borrowing.

Certainly, for a successful interaction with world science it is necessary to undertake some additional practical steps.

First of all, for a long period of time Russian researchers need to make an inventory of the scientific facilities, to define (and to precisely name) leading schools and widely present them for international attention. It's true, "Today is no classification of main theoretic divisions of mass communication research in Russia. On the one hand, we can see a terminological mess in the objects of theoritizing..." (Dunas, 2013a, p. 89). To improve the situation the ambitious research project "History of journalism theories in Russia" was developed at St Petersburg State University. The project includes some theoretical directions:

- Historical-theoretical;

- Normative;

- Social-philosophical;

- Political;

- Sociological;

- Psychological;

- Cultural;

- Aesthetic.

The book on the project results was published last year in Russian (Korkonosenko, 2014). The next stage should be devoted to observation, evaluation, and estimation of the journalism theories in horizontal dimension, means modern state of affairs in the theories, as well as their development prospects.

Undoubtedly, it is necessary to translate a significant part of the scientific exchange into foreign languages, including this project, mainly into English. National pride should not prevent people from seeing that English has occupied a place as the language of international professional interaction. This suggestion represents only the acknowledgement of a real state of affairs, instead of an antipatriotic attack. If on a parameter "The global importance of some languages relative to English" to give English language 100 points, German will receive 42 points, Spanish - 31, and Russian - only 3 (Lazzari, 2006, p. 12). But ideas shouldn't be unified, they belong to concrete professional culture, and in this way they belong to the world.

\section{References}

Curran, J., \& Park M. J. (Eds.). (2000). De-westernizing media studies. New York: Routledge.

Downing, J. D. H. (1996). Internationalizing media theory: Transition, power, culture - Reflections on media in Russia, Poland and Hungary, 1980-95. London: Sage Publications Ltd.

Dunas, D. V. (2013a). Mapping mass communication theories in contemporary Russia. In E. L. Vartanova (Ed.), World of Media. Yearbook of Russian Media and Journalism Studies (pp. 88-107). Moscow: Faculty of Journalism of Lomonosov Moscow State University; MediaMir.

Dunas, D. (2013b). Studying in the field of mass communication: Foreign researchers' view of the issue. Medi@lmanakh, 1, 5-15.

Ekecrantz, J. (2007). Media and communication studies going global. Nordicom Review, Jubilee Issue, 169-181.

Hanitzsch, Th., \& Mellado, C. (2011). What shapes the news around the world? How journalists in 18 countries perceive influences on their work. In R. SalaverrHa (Ed.), Proceedings of the 2011 ECREA/CICOM Diversity of Journalisms Conference (p. 398). Pamplona (Spain): University of Navarra.

Jakubowicz, K. (2001). Rude awakening: Social and media change in Central and Eastern Europe. The Public, $8(1), 59-80$.

Korkonosenko, S. G. (Ed.). (2014). Theories of journalism in Russia: Origin and development. St Petersburg: St Petersburg University Publishing House.

Lazzari, G. (Project Manager). (2006). Human language technologies for Europe. Trento: Tipolitografia TEMI. 
McQuail, D. (2009). Diversity and convergence in communication science: The idea of "national schools" in the European area. In N. Carpentier et al. (Eds.), Communicative approaches to politics and ethics in Europe: The intellectual work of the 2009 ECREA European media and communication doctoral summer school (pp. 281-292). Tartu: Tartu University Press.

Parthé, K. (1992). Russian village prose: The radiant past. Princeton: Princeton University Press. .

Podorvanyuk, N. (2013, October 6). To Russia happens nothing. Gazeta.ru. Retrieved from http://www.gazeta.ru/science/2013/06/10_a_5375045.shtml

Pöttker, H. (2011). Ot novostnoi funkcii k orientiruyushei [From the news function to the orienting]. In S. G. Korkonosenko (Ed.), Sredstva massovoi informacii v sovremennom mire. Peterburgskie chteniya [Media in the contemporary world. Petersburg readings] (pp. 10-13). St Petersburg: Faculty of Philology, St Petersburg State University.

Sapunov, V. I. (2012). Massovaya kommunikaciya: koncepcii zapadnyh issledovatelei [Mass communication: The concepts of western researchers]. Voronezh: Faculty of Journalism of Voronezh State University.

Seiffert, W. (2007). Russia's role in the new world order. Current Concerns, 14. Retrieved from http://www.currentconcerns.ch/index.php?id=455

Sparks, C. (2008). Media systems in transition: Poland, Russia, China. Chinese Journal of Communication, 1(1), $7-24$.

Thussu, D. K. (Ed.). (2009). Internationalizing media studies. London and New York: Routledge.

Vartanova, E. (2012). The Russian media model in the context of post-Soviet dynamics. In D. C. Hallin \& P. Mancini (Eds.), Comparing media systems beyond the Western world (pp. 119-142). New York: Cambridge University Press.

Vorontsov, A. V., \& Volovich, V. N. (Eds.). (2012). Modernizaciya rossiiskogo obshestva: Real'nost' i mify [Modernization of the Russian society: Reality and the myths]. St Petersburg: Severnaya Zvezda.

Waisbord, S. (2013). De-Westernization and cosmopolitan media studies. Retrieved from http://www.academia.edu/2971672/De-Westernization_and_cosmopolitan_media_studies

Wasserman, H., \&de Beer, A. S. (2009). Towards de-Westernizing journalism studies. In K. Wahl-Jorgensen, \& Th. Hanitzsch (Eds.), The handbook of journalism studies (pp. 428-438). New York: Routledge.

\section{Copyrights}

Copyright for this article is retained by the author(s), with first publication rights granted to the journal.

This is an open-access article distributed under the terms and conditions of the Creative Commons Attribution license (http://creativecommons.org/licenses/by/3.0/). 